\title{
OBITUARIES
}

\section{Professor O. R. Gurney, MA, DPhil, FBA}

(1911-2001)

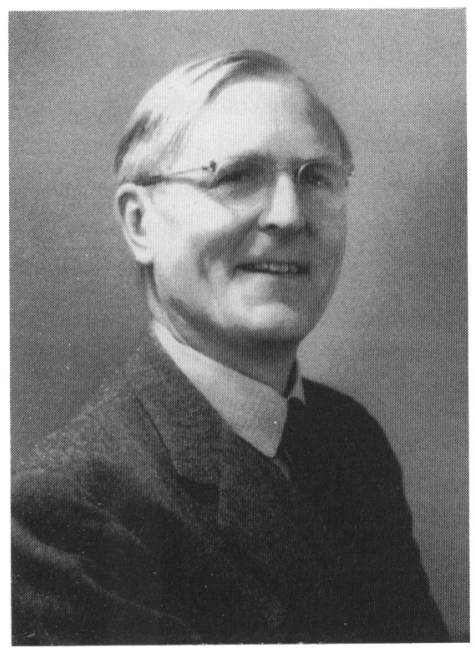

Professor Oliver Gurney died peacefully on 11 January, following a short illness, just two weeks before his ninetieth birthday.

He devoted his academic life to the study of the ancient Near Eastern civilisations whose records are preserved in cuneiform writing. He was the most distinguished British cuneiform scholar of his generation and represented one of the last surviving links with the first era of Assyriology, through A. H. Sayce, who inspired Oliver's uncle John Garstang to write The Land of the Hittites in 1910. It was Garstang, Professor of Archaeology at Liverpool, who persuaded Oliver himself to take up this study. Gurney described Sayce as a spiritual ancestor and recalled meeting him, aged 87 , at the excavations of Jericho in 1931 - a vigorous old gentleman in full clerical dress despite the oppressive heat. Sayce was the last of the Assyriologists of the old school of Rawlinson, Oppert and Hincks, and had been a friend of Schliemann, Georg Curtius and Gladstone.

Oliver Robert Gurney was born in London on 28 January, 1911, the only child of Robert Gurney, a noted zoologist from an old Norfolk family, and of Sarah Gamzu Garstang, daughter of Walter Garstang, MD, MRCP. From Eton, Oliver went in 1929 to read classical Greats at New College, Oxford, where his interests came to focus especially on Homer. His uncle drew his attention to the cuneiform archives in Hittite, newly identified as the oldest Indo-European language, which had been recently excavated in Turkey, and which were beginning to reveal the history behind the Homeric epics. Oliver's enthusiasm, fired then for the infant discipline of Hittite studies, never waned.

So before taking his finals he called on the Professor of Assyriology, Stephen Langdon, to say that he wished to learn Mesopotamian cuneiform as a stepping-stone to Hittite. Gurney recalled that Langdon looked him up and down before asking, "Is your health good?" He debated ever afterwards whether this was a serious question prompted by an anxiety that Gurney's health might not withstand such a strenuous career, or a joke implying that he was out of his mind. In 1933 he began to study Akkadian and Sumerian under Langdon (who had been a pupil of Scheil, Fossey and Thureau-Dangin), and then spent $1935-6$ at Berlin University being initiated into the mysteries of the Hittite language under Hans Ehelolf, also attending lectures by Erich Ebeling. Gurney completed his Oxford doctorate with an exemplary edition of the Prayers of the Hittite King Mursili II, published in 1940.

During the war he served in the Royal Artillery, reaching the rank of captain, and was attached for four years to the Sudan Defence Force, taking part in the campaigns in Eritrea and Abyssinia. He used to say that he had learnt the necessary Arabic on the boat travelling out to Africa.

In 1945 Oxford proposed to refill the post in Assyriology vacated by the death of Reginald Campbell Thompson. Sir Godfrey Driver told the authorities that a trained cuneiformist called Gurney would shortly be demobilised. Gilbert Muray wrote to Oliver, addressing the letter to Bimbashi O. Gurney (in the Sudan Defence Force captains were still called by the old Ottoman title bimbashi): "We are greatly interested, indeed almost excited, by the correspondence from Driver about the vacant Readership in Assyriology. It seems to be a place created for you." There was another candidate, and it seems that Oliver was at first hesitant, because his principal interest was Hittite. But his mother wrote to him, "Apparently the Readership would include Hittite as they take it to be for any Cuneiform study". So, while still a bimbashi, Gurney was appointed as 
Shillito Reader in Assyriology at Oxford, a post which he held with distinction until 1978, becoming a Fellow of Magdalen College from 1963 and ad hominem Professor from 1965 . He divided his energies between Assyriology and Hittite Studies, announcing on his retirement that he would devote himself fully to Hittite thenceforth. Among his students over more than thirty years were several who themselves later occupied university or museum posts in these fields.

As a teacher he was benign, and generous with his time. In any class, within minutes the table would be littered with books snatched from the shelves to pursue some point. His students remember the hospitality which he and Diane provided at Bayworth Corner, their house on Boars Hill near Oxford.

Although he took part in two of his uncle's excavations in southern Turkey, he decided that his own best contribution would be the copying and study of cuneiform tablets. "Just copy what you see", was the advice he gave about copying, and his meticulousness, combined with a readiness to go back to the original clay tablet years later and correct his own earlier readings, has provided an example to colleagues. This led to a series of careful publications, some in collaboration with other scholars. Among them was The Sultantepe tablets (vol. 1 produced with J. J. Finkelstein, vol. 2 with his Oxford colleague Peter Hulin), making available the contents of a newly-excavated and well-stocked Assyrian scribal library from Sultantepe in Turkey, including the amusing tale "The poor man of Nippur". He later returned to study this tale from a literary and folklore perspective. With Samuel Noah Kramer he produced Sumerian literary texts in the Ashmolean Museum (OECT 5), a volume of important Sumerian literary compositions in Oxford, and Middle Babylonian legal and economic texts from Ur, copies and editions of Kassite-Period documents originally excavated by Woolley. Undeterred in his seventies by the newest technology, Gurney computer-typeset the volume himself. A further meticulous volume of Babylonian literary and scientific works followed (Literary and miscellaneous texts in the Ashmolean Museum, OECT 11), also from his notional retirement.

Oliver was a music-lover, and at the time of his death was immersed in Bryan Magee's new book on Wagner, his favourite opera-composer. But he also became interested in Babylonian music and made a considerable contribution to modern understanding of it, writing several papers on the subject. Although no ancient music survives, one of the tablets from Ur which he had copied contained the names for the strings of a harp, and with the collaboration of musicologists he was able to prove conclusively that the Babylonians used a heptatonic scale with seven octave species anticipating the Greeks. A performance including reconstructed Near Eastern music took place in the Ante-Chapel at Magdalen, with David Wulstan conducting his specialist choir The Clerkes of Oxenford.

Oliver maintained the habit of letter-writing, keeping in academic contact with both professionals and amateurs, arguing through textual and historical problems with inexhaustible patience and courtesy tempered with unremitting acuity, perfectly lucid to the end. He said he knew more about the archeology of Knossos — which he frequently discussed with Leonard Palmer - than about any Mesopotamian site. This was because Oliver was such a good listener and critic. His voluminous correspondence was retained and indexed, along with other papers - including his collection of photographs of inadvertently humorous traffic signs.

His deservedly popular Penguin book The Hittites was published in 1952 and has remained in print ever since, most recently revised in 1999 and translated into several languages. It provides readers with an excellent and reliable synthesis of the subject where his deepest interests lay. $\mathrm{He}$ shared John Garstang's long-standing fascination with the problems of identifying localities within the Hittite Empire, and on his uncle's death in 1956 he undertook to complete their joint work on the subject, which appeared in 1959 as The geography of the Hittite Empire. In 1959 he was elected a Fellow of the British Academy, and gave the Schweich Lectures in 1976, published as the authoritative volume entitled (with characteristic modesty) Some aspects of Hittite religion (1977).

He first became a member of the Council of the British School of Archaeology in Iraq in 1954 and was a regular attender at Council meetings, being elected a Vice-President in 1995 "in recognition of his long and valuable service to the School as a member of Council". He was closely associated also with the establishment of the British Institute of Archaeology at Ankara, of whose Council he was a member from the first, and was Deputy Chairman from 1965 and an 
obvious choice as President from 1982. From 1952 he was assistant editor (to Gordon Childe), and from 1956 until 1997 sole editor, of Anatolian Studies, the Institute's journal. He was awarded an honorary Doctorate of Higher Letters from Chicago (1991), doubtless in part for his contribution of lexical material from tablets in the Ashmolean to the series Materials for the Sumerian Lexicon and the Chicago Assyrian Dictionary. Other honours included Foreign Membership of the Royal Danish Academy of Science and Letters (1976), and election as a Freeman of the City of Norwich.

With exaggerated modesty he once described himself as "just a bookworm". This was not true at all. Those who knew him will remember him, on the contrary, as a meticulous and energetic scholar of ample learning, always ready to engage with others, or to be enthused by new discoveries. But above all, we remember him as a generous teacher, and a kind and dear friend.

$\mathrm{He}$ is survived by his wife Diane, whom he married in 1957, and stepdaughter Caroline.

J. A. Black

Expanded from an obituary which appeared in The Times, 24th January 2001.

\section{Miss Geraldine Talbot M.A.} (1908-2000)

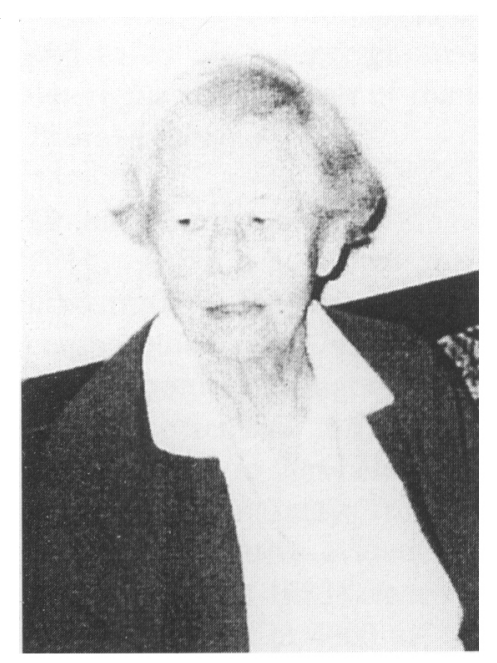

We remember Gerry here especially for her more than 20 years of devoted service to the British School of Archaeology in Iraq, first as Assistant Secretary for Publications, and from 1963 to 1976, Honorary Secretary during the occasionally difficult period when the School had finally achieved its full establishment in Baghdad. She then resumed her responsibility for the School's publications until her final retirement in 1983, but she never lost her interest in its affairs. We all look back with gratitude for Gerry's constant and loyal support. She never failed us and she never fussed. We remember her with great affection.
Gerry Talbot died on September 19,2000 at the age of 92, after a short illness following a fall at her home.

After reading Modern Languages at Oxford, Gerry served with the First Aid Nursing Yeomanry as a military ambulance driver throughout the blitz, largely in dockland and south-east London, and was then commissioned into the Auxiliary Territorial Service with the rank of captain. In 1946 she became Assistant Librarian at the Institute of Archaeology, University of London and, after the retirement of Joan du Plat Taylor, Librarian from 1962 to 1976 . All of us at the Institute during that time owe her a great debt for her cheerful readiness to help staff, students and visiting scholars alike with their problems, great or small, over the whole field of archaeological literature, of which she had an extraordinary knowledge. On the practical side, she had experience on British digs, but her own main interest lay in the Near East, where she took part in excavations at Busairah, Petra, Jerusalem and Jericho.

David Oates 